\title{
EFFECT OF DIETARY ERUCA SATIVA SEEDS MEAL AND NANO- CHITOSAN ON PERFORMANCE AND RELATED GENE EXPRESSION TO GROWTH AND LIPID PROFILE IN BROILER CHICKS
}

\author{
Hayam M. A. Abou El-Maaty ${ }^{1 *}$, M. H. Abd El-Aziz ${ }^{2}$, M. Z. El-Diasty ${ }^{2}$ and Eman A. El-Said ${ }^{3}$ \\ ${ }^{1}$ Poultry Production Department, Faculty of Agriculture, Mansoura University, Egypt. \\ ${ }^{2}$ Genetics Department, Faculty of Agriculture, Mansoura University, Egypt. \\ ${ }^{3}$ Poultry Production Department, Faculty of Agriculture, Damietta University, Egypt.
}

*Corresponding author: Hayam M. A. Abo El-Maaty; Poultry Production Dept., Fac. Agric., Mansoura University,Mansoura 35516, Egypt. Tel: $+201008961731 \quad$ Fax: +20502245268

(Received 14/11/2019, accepted 23/12/2019)

\section{SUMMARY}

$\mathrm{T}$ This study was carried out to evaluate the impacts of inclusion of two plant proteins (soybean meal or rocket meal) in the starter and growing-finishing diets fed with/without nano-chitosan for Cobb500 one-day old broiler chicks on growth performance and serum parameters, as well as expression patterns of PPAR $\alpha, P P A R \gamma$ and IGF-1 genes in liver tissue. A total of 220 chicks were randomly distributed into four treatments in a floor pen under hygienic conditions. Results indicated that birds fed 7.5\% rocket seed meal (RSM) exhibited the best means of FBW, BWG and FCR. While least feed intake with higher FBW and BWG was found in nano-chitosan fed birds. RSM fed chicks had a significant decrease in serum levels of TG, LDL, total lipids, AST and ALT with insignificant changes in serum albumin, total cholesterol and HDL compared with the control group. Significant increases in serum levels of IgG, IgM, IgA, CAT, TAC, SOD, T3, T4 and FSH were found in RSM-fed birds as compared to the control group. Insignificant differences were noted in gene expression among the different experimental groups of chicks regarding IGF-I and PPARa genes. While the PPAR $\gamma$ gene showed significant decreases in transcriptional activity in chickens fed on RSM with nano-chitosan. Our findings declared that RSM can be used in chicks diet up to $7.5 \%$ singly or with nano-chitosan without any adverse effect on performance, blood parameters and related gene expression with a beneficial effect of RSM with nano-chitosan in reducing the lipogenesis in broiler chicks.

Keywords: Eruca sativa seed meal; nano-chitosan; broiler performance; blood parameters and gene expression.

\section{INTRODUCTION}

Basically, protein nutrition represents a principal challenge to poultry production mainly in the area where protein-rich feedstuffs are restricted (Beski et al., 2015). Formulating broiler diets based on corn and soybean meal has augmented soybean meal demands and consequently raised the feeding cost. Two possible approaches can be employed to reduce the feed cost for broiler chicks. The first is the use of the alternative locally available protein sources. Rocket seed meal is predictable to increase in local market owing to its use as an aromatic plant. Furthermore, research work with RSM is finite. Additionally, El-Shafei et al. (2007) observed that RSM can fruitfully be used in growing Japanese quail diets as a partial substitute for SBM up to $32 \%$ without any unfavorable effects on their growth performance, carcass characteristics or blood constituents. They also, indicated that RSM can serve as immune-stimulant due to its antioxidant properties. Abo El-Maaty (2009) reported that hens fed the RSM-containing diets displayed no significant differences in DFI, FCR and BWG compared with the control group. 
Chitosan nanoparticles (ChNPs) exhibit more superior activities than chitosan since nanonization possesses have many advantages, such as increasing compound solubility and improving its absorbability (Wen et al., 2011). Not surprisingly, ChNPs have been showed to have an immune-enhancing effect, antimicrobial activity and anticancer properties (Iqbal et al., 2003). It also has potential adjuvant properties, such as promoting endocytic uptake and elevating immune responses. Additionally, ChNPs possess lower cytotoxicity and more stability (Neimert-Andersson et al., 2011). If we try to view some of this genetic research positively, we may open doors to drastically change the future of the poultry industry. The nutritional effects can be assessed by measuring of gene expression levels in liver and muscle tissues for nuclear hormone receptors such as Peroxisome Proliferator-Activated Receptors (PPARs) (Wahle et al., 1995 and 2003) and growth factors such as IGF-1 (insulin like growth factor-1) which depended on the nutrition status (Heck et al., 2003 and Guernec et al., 2004). Where, IGF-1 and PPARs mRNA contents in tissues could give valuable information for formulating an optimal feed for broiler chickens. Demonstrating that $P P A R \gamma$ the important metabolic effect of $P P A R \gamma$ in chicken is its task in formation of fat cells (adipogenesis) and tissues (Navidshad and Royan, 2015). On the other hand, Peroxisome Proliferator-Activated Receptor $\alpha(P P A R \alpha)$ increase the fatty acid oxidation through upregulating the expression of acyl-coenzyme A oxidase and the carnitine palmitoyl transferase enzymes (Bell et al., 1998 and Pineda et al., 1999).

Therefore, the existing study was planned to assess the effects of Rocket seed meal (RSM) as a partial substitute for SBM and chitosan nanoparticles on productive performance, blood biochemicals and immunological responses and related gene expression to growth and lipid profile of broiler chicks.

\section{MATERIALS AND METHODS}

The present experiment was carried out at the Poultry Research Unit, Agricultural Research and Experimental Center, Faculty of Agriculture, Mansoura University, Egypt, under climates of autumn season in Egypt (October to November, 2018). The range of environmental temperature during this period was $33-38^{\circ} \mathrm{C}$. The main purpose of the study was to illustrate the possible beneficial effect of feeding an untraditional source of plant protein without or with nano-chitosan on subsequent growth performance, some physiological and immunological responses and gene expression traits in broiler chicks.

\section{Preparation of chitosan nanoparticles:}

The ionic gelation method was used for the preparation of nanoparticles of hydrophobic polymers. The preparation method was extremely mild and involved a mixture of two aqueous phases at room temperature. In the first phase, $0.2 \mathrm{~g}$ chitosan (Sigma-Aldrich, Egypt) was dissolved with $200 \mathrm{ml}$ distilled water containing $1 \mathrm{ml}$ acetic acid at $25^{\circ} \mathrm{C}$ for $30 \mathrm{~min}$. The mixture $\mathrm{pH}$ was adjusted to be 7.20 , while in the other phase $0.066 \mathrm{~g}$ polyanion sodium tripolyphosphate (TPP) was dropped slowly with stirring. Zeta sizer showed the size of nano-chitosan was between $30 \sim 40 \mathrm{~nm}$ (Fig. 1). The sub main factor was chitosan nanoparticles coating applications $10 \mathrm{ml} / \mathrm{Kg}$ diet.

\section{Experimental design, birds and diets:}

The experimental design used was a completely randomized factorial design, with two sources of plant protein (soybean meal or rocket seed meal) in the starter and growing-finishing diets fed without or with nano-chitosan. Thus, there were 4 dietary treatments. Each diet was fed to 55 one d-old unsexed Cobb 500 broiler chicks divided equally among five replicates. Each replication of chicks was kept in floor pen $(100 \times 150 \mathrm{~cm})$. The experimental chicks were distributed randomly among the experimental diets at day of hatch, with approximately similar initial live body weights among replicates and treatments. The diets were formulated based the nutrients composition of feedstuffs as reported by NRC (1994) except for rocket seed (Eruca sativa) meal (RSM) which was determined, and all feed formulations met nutrient requirements of broiler chicks (NRC, 1994). Feed and water were offered ad libitum throughout the experiment. Broiler chicks were kept under the same managerial and hygienic conditions and exposed to $23 \mathrm{~h}$ light/d up to $42 \mathrm{~d}$ of age. Common management practice was used for brooding and rearing the birds. Vaccination and veterinary care were made according to common veterinary medicine practice for chicks. Experimental diets are shown in Table (1).

\section{Criteria of response:}

\section{Performance traits:}

Chicks were weighed at one and $42 \mathrm{~d}$. At the end of the experimental period, body weight (BW), body weight gain $(\mathrm{BWG})$ and feed intake (FI) of broilers were recorded. Feed conversion ratio (FCR) was 
calculated by dividing FI (g) by body weight gain $(\mathrm{g})$. The study was ended at the 6 weeks of the experiment.

\section{Slaughter test and blood samples:}

Six blood samples were collected during slaughtering in heparinized tubes. Serum was separated by centrifugation at $3000 \mathrm{rpm}$ for 15 minutes and stored rapidly at $-20^{\circ} \mathrm{C}$ until analysis. Blood serum concentrations total protein (TP), albumin (Alb), triglycerides (TG), total cholesterol (Chol) and highdensity lipoprotein-cholesterol (HDL-C) and were determined using commercial kits. Blood serum level of low-density lipoprotein-cholesterol (LDL-C) was also estimated by using the equation of Friedewald et al. (1972), as follows: LDL-C=Total cholesterol-(HDL-C+vLDL); where vLDL are very low-density lipoprotein which was calculated as concentration of serum triglycerides divided by 5. Globulin was calculated by differences between total protein and albumin. Also, total antioxidant capacity (TAC), malondialdehyde (MDA), superoxide dismutase (SOD), catalase (CAT), immunoglobulins G (IgG, IgA, IgM), triiodothyronine (T3), thyroxin (T4) and follicle-stimulation hormone (FSH) and activity of liver enzymes alanine aminotransferase (ALT) and aspartate aminotransferase (AST) and alkaline-phosphatase (ALP) were determined by commercial kits.

Table (1): Composition and chemical analyses of the tested diets fed to broiler chicks from 0 to 6 weeks of age.

\begin{tabular}{|c|c|c|c|c|}
\hline \multirow{2}{*}{ Ingredient (\%) } & \multicolumn{2}{|c|}{$\underline{\text { Starter diet }}$} & \multicolumn{2}{|c|}{ Growing and finisher diet } \\
\hline & Control & RSM & Control & RSM \\
\hline Ground yellow corn & 61.50 & 58.23 & 67.20 & 64.70 \\
\hline Soybean meal (44\%CP) & 16.00 & 9.67 & 15.00 & 8.00 \\
\hline Corn gluten meal $(60 \% \mathrm{CP})$ & 16.50 & 18.3 & 12.00 & 14.00 \\
\hline Rocket (Eruca sativa) seed meal & - & 7.50 & - & 7.50 \\
\hline Sunflower oil & 1.00 & 1.30 & 1.00 & 1.00 \\
\hline Ground limestone & 2.00 & 2.00 & 2.00 & 2.00 \\
\hline Dicalcium phosphate & 1.80 & 1.80 & 1.80 & 1.80 \\
\hline Vitamins and minerals Premix ${ }^{3}$ & 0.30 & 0.30 & 0.30 & 0.30 \\
\hline Common salt $(\mathrm{NaCl})$ & 0.30 & 0.30 & 0.30 & 0.30 \\
\hline DL-Methionine & - & - & - & - \\
\hline L-Lysine-HCl & 0.60 & 0.60 & 0.40 & 0.40 \\
\hline Total & 100 & 100 & 100 & 100 \\
\hline \multicolumn{5}{|c|}{ Calculated analysis (As fed basis: NRC, 1994) } \\
\hline Metabolizable energy (ME), Kcal/kg & 3149 & 3126 & 3143 & 3110 \\
\hline Crude protein $(\mathrm{CP}), \%$ & 23.06 & 23.08 & 20.13 & 20.05 \\
\hline Ether extract (EE), \% & 3.88 & 5.03 & 3.97 & 4.86 \\
\hline Crude fiber (CF), \% & 2.69 & 2.60 & 2.68 & 2.57 \\
\hline Calcium, $\%$ & 1.20 & 1.18 & 1.20 & 1.18 \\
\hline Nonphytate P, \% & 0.45 & 0.45 & 0.45 & 0.44 \\
\hline Lysine, \% & 1.22 & 1.16 & 1.10 & 0.94 \\
\hline Methionine, $\%$ & 0.46 & 0.47 & 0.39 & 0.41 \\
\hline Methionine + Cystine, $\%$ & 0.85 & 0.89 & 0.74 & 0.78 \\
\hline \multicolumn{5}{|c|}{ Determined analysis (DM basis: A.O.A.C., 1990) } \\
\hline Dry matter (DM), \% & 92.93 & 92.89 & 91.87 & 91.54 \\
\hline Crude protein $(\mathrm{CP}), \%$ & 24.81 & 24.85 & 21.91 & 21.90 \\
\hline Ether extract (EE), \% & 4.18 & 5.42 & 4.32 & 5.31 \\
\hline Crude fiber (CF), \% & 2.89 & 2.80 & 2.92 & 2.81 \\
\hline Ash, $\%$ & 9.11 & 9.16 & 8.71 & 8.92 \\
\hline Nitrogen-free extract (NFE), \% & 59.01 & 57.77 & 62.14 & 61.06 \\
\hline
\end{tabular}

${ }^{I}$ Premix at $0.30 \%$ of the diet supplies the following $/ \mathrm{kg}$ diet:

Vit.A,1000IU;Vit.D, 2000IU;Vit.E,10mg;Vit.K,1mg;Vit.B1,5mg;Vit.B2,5mg;Vit.B6,1.5mg;Vit.B12,0.01mg;Folic acid,0.35mg;Biotin,0.05mg;Pantothenic acid,10mg;Niacin,30mg;Choline chloride, 250mg;Fe,30mg;Zn, 50mg;Cu, $4 \mathrm{mg}$ and $\mathrm{Se}, 0.1 \mathrm{mg}$. 


\section{Gene expression analysis:}

\section{RNA isolation and cDNA synthesis:}

Liver tissue samples (three birds from each treatment) were taken immediately after slaughter, instantly frozen in liquid nitrogen and stored (about two d.) at $-80^{\circ} \mathrm{C}$ until use. From each sample, total RNA was isolated using Gene JET RNA Purification Kit (Thermo Scientific cat No. \#Ko731) as stated by manufacturers instruction. Purity and concentration of isolated RNA were checked by Nanodrop spectrophotometer (Thermo Fisher Scientific Inc.) and by electrophoresis using ethidium bromide staining, 18S and 28S rRNA were appeared as sharp two bands. After that, DNase I, RNase-Free was used to removal of genomic DNA from RNA preparations.

In order to cDNA synthesis, total RNA $(1 \mu \mathrm{g})$ was reverse transcribed with Revert Aid ${ }^{\mathrm{TM}}$ First Strand cDNA Synthesis Kit (Thermo Scientific) was used following the protocol provided by the producer. The PCR amplification was performed for cDNA synthesis by Stepone (Applied Biosystems). Next, Ribolock RNase inhibitor were added, then terminate the reaction by heating at $70^{\circ} \mathrm{C}$ for 5 min and stored at $-80{ }^{\circ} \mathrm{C}$ until use.

\section{Primer design:}

Specific primer pairs (forward and reverse) for target and reference genes of interest in this study were designed using Primer-BLAST and based on previous reports (Table 2). These primers were procured from Introgen (Thermo Fisher Scientific) and checked on cDNA samples using PCR then gel electrophoresis, where produced specific PCR product (Table 2).

Table (2): The specific primers for target and reference genes of used in quantitative real time PCR analysis.

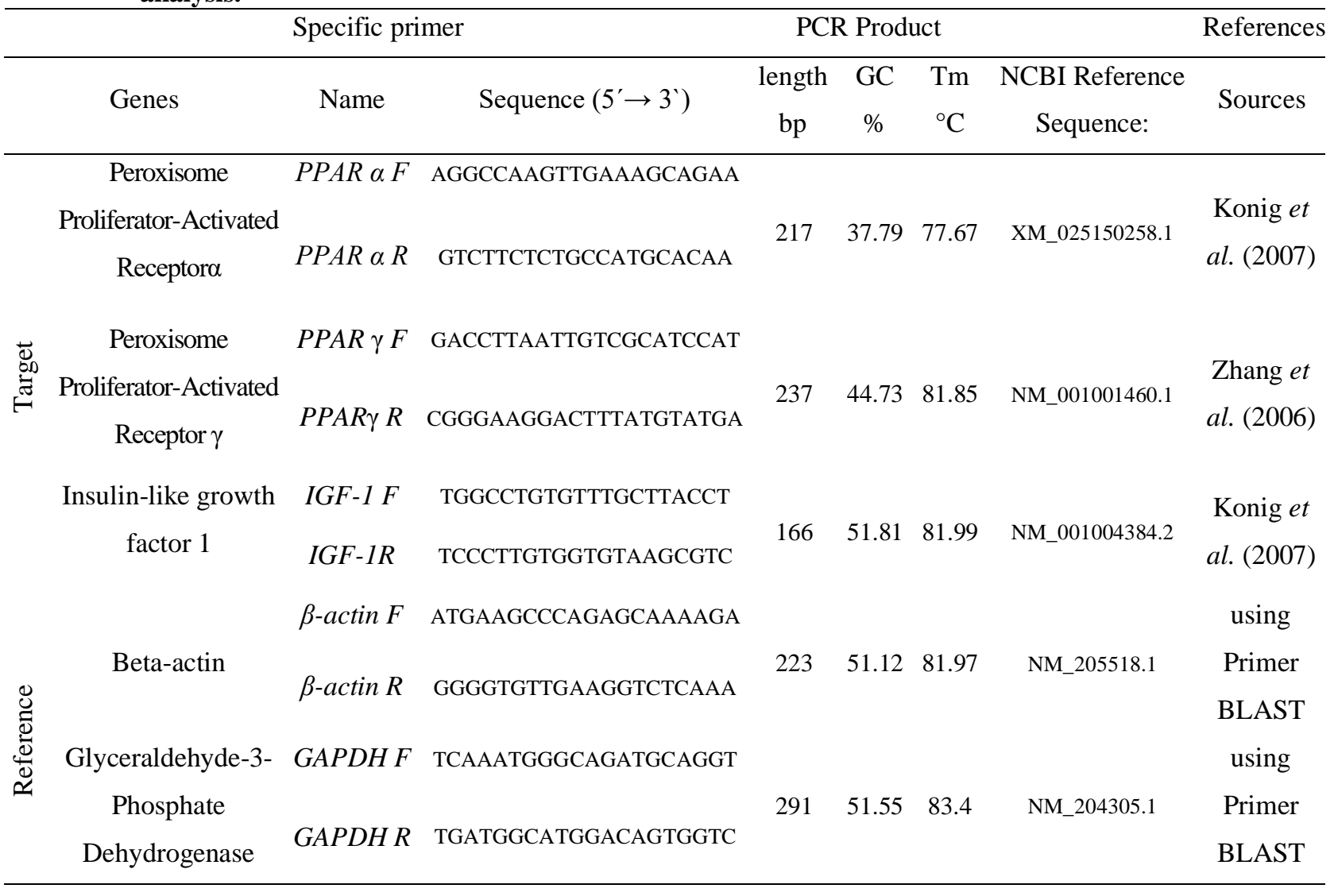

\section{Quantitative RT-PCR:}

Quantitative 2-step RT-PCR was performed using a Maxima SYBR Green qPCR Master Mix (2X),ROX Solution provided protocol in Veriti ${ }^{\circledR}$ 96-well thermal Cycler (Applied Biosystems).The real time PCR program was as follows : initial denaturation at $95{ }^{\circ} \mathrm{C}$ for $10 \mathrm{~min}$.; 40 cycles of denaturation at $95^{\circ} \mathrm{C}$ for $15 \mathrm{sec}$; annealing/extension at $60{ }^{\circ} \mathrm{C}$ for $60 \mathrm{sec}$. Data acquisition performed during the annealing/extension step. 
Primers specificity for target and reference genes were checked by evaluation of melting curves of RT- PCR products which were conducted from $55^{\circ} \mathrm{C}$ to $95{ }^{\circ} \mathrm{C}$ to confirm the amplification of single amplicon (Fig. 2).

Expression patterns of Target genes (PPAR $\alpha, P P A R \gamma$ and IGF-1) in liver tissue from sample of control and treatments were determined using $2^{-\Delta \Delta \mathrm{C}_{\mathrm{T}}}$ method according to Livak and Schmittgen (2001) and normalized by the expression of reference or housekeeping genes ( $\beta$-act and GAPDH) as endogenous control. The output data were obtained as fold change (FC) relative to the control (fold relative expression). The relative expression values were automatically generated by entering $\mathrm{C}_{\mathrm{T}}$ values from housekeeping and target genes into Microsoft Office Excel sheet contain equations of $2^{-\Delta \Delta \mathrm{C}_{\mathrm{T}}}$ method. The comparison of gene expression data was carried out using SAS 9 Software and the significance of difference was determined according to Duncan's Multiple Range Test at $\mathrm{P} \leq 0.05$.

A correlation coefficient and linear regression between normalized expression levels over to $\beta$-act and GAPDH as well as between relative gene expression for genes of interest and performance traits were calculated using Mintab17 statistical Software.

\section{Statistical analysis:}

Our data were subjected to statistical analysis as two factors-factorial analysis of variance using SAS Program (2004). Means were separated ( $\mathrm{P} \leq 0.05)$ using Duncan's multiple range test (Duncan, 1955), for the comparison among means of the tested rations when the main effects were significant. The following statistical model was used:

$$
x_{i j k}=\mu+L_{i}+P_{j}+(L P)_{i j}+e_{i j k}
$$

Where:

$x_{\mathrm{ijk}}=$ an observation,

$\mu=$ overall mean,

$\mathrm{L}_{\mathrm{i}}=$ effect of protein source ( $\mathrm{i}=1$ and 2 ),

$P_{j}=$ effect of level Chitosan nanoparticles $(j=1$ and 2$)$,

$(\mathrm{LP})_{\mathrm{ij}}=$ effect of Interaction between $\mathrm{LP}(\mathrm{ij}=1,2,3$ and 4$)$ and

$\mathrm{e}_{\mathrm{ijk}}=$ random error

\section{RESULTS AND DISCUSSION}

\section{Productive performance:}

Data on the impacts of feeding the experimental diets and nano-chitosan additives on the productive performance of broiler chicks, including, body weight (BW), body weight gain (BWG), feed intake (FI) and feed conversion ratio (FCR) are presented in Table (3). Fed nano-chitosan-included diets consumed the least amount of feed but had a higher FBW and BWG in comparison with the control chicks. Irrespective of the influence of dietary protein sources, nano-chitosan-supplemented diets significantly $(\mathrm{P} \leq 0.01)$ improved the FCR as compared to their control counterparts (the main effect of feeding the two plant protein sources, SBM and RSM) produced significant effects on FBW, BWG and FCR $(\mathrm{P} \leq 0.01)$ during the period from 0 to $42 \mathrm{~d}$. of age. The best means of FBW, BWG and FCR were achieved by chicks fed the diet containing 7.5\% rocket seed meal (RSM) as compared to their control birds. The improvements in FBW, BWG and FCR due to the impact of dietary RSM were estimated to be 8.88, 8.68 and $7.43 \%$ for chicks fed the diet containing 7.5\% RSM, respectively. The superiority of diets containing SBM and RSM indicated a complementary effect which might have increased availability of amino acid and/or eliminate the anti-nutritional substance or amino acid imbalance (Irish and Balnave, 1993 and Attia et al., 2003). Therefore, the enhancement in growth performance in response to feeding RSMcontaining diets could be attributed to the improved nutrient availability in the diets compared with their control counterparts. There were no significant differences in FI between groups of chicks fed the tested diets containing the two plant protein sources.

Osman et al. (2004) reported that feeding either radish or rocket meals up to $15 \%$ instead of a part of soybean meal in broiler diets had no effect on their live body weight. Abdo (2003) found that the best body weight gain of broilers was attained by the groups received rocket seed meal at levels of 10 and $25 \%$ in place of soybean protein. El-Tohamy and El-Kady (2007) found that using rocket meal at 50\% a replacement of dietary soybean meal caused a significant increment of daily body gain, and daily feed intake, and improved feed conversion of rabbits. They suggested that such improvement may be 
attributed to the properties of the tested material that could act as anti-bacteria, anti-protozoal, anti-fungal and antioxidants. Yasser et al. (2015) recommended that black cumin, mustard, sesame and rocket seed meals can safely be used as supplements at 3\% level in broiler rabbit diets in order to get higher economic efficiency without any adverse effect on the rabbit performance.

Table (3): Growth performance (from 0 to 42-d.-old) of broiler chicks fed diets containing two protein sources without or with nano-chitosan addition.

\begin{tabular}{|c|c|c|c|c|c|}
\hline \multirow[t]{2}{*}{ Fact1 } & IBW & FBW & BWG & FI & FCR \\
\hline & $(\mathrm{g})$ & $(\mathrm{g})$ & $(\mathrm{g})$ & (g) & $(\mathrm{g}: \mathrm{g})$ \\
\hline \multicolumn{6}{|l|}{ Protein sources (A) } \\
\hline Soybean meal (A1) & 44.8 & $2368.0^{\mathrm{b}}$ & $2323.3^{\mathrm{b}}$ & 4054.4 & $1.75^{\mathrm{b}}$ \\
\hline Rocket seed meal (A2) & 44.0 & $2573.5^{\mathrm{a}}$ & $2529.5^{\mathrm{a}}$ & 4074.5 & $1.62^{\mathrm{a}}$ \\
\hline SEM & 0.25 & 35.18 & 50.25 & 09.31 & 0.03 \\
\hline Sig. & NS & $* * *$ & $* * *$ & NS & $* *$ \\
\hline \multicolumn{6}{|l|}{ Feed additives } \\
\hline (0.0g ChNPs/kg diet) B1 & 44.15 & $2378.0^{\mathrm{b}}$ & $2333.9^{\mathrm{b}}$ & $4188.5^{\mathrm{a}}$ & $1.79^{\mathrm{b}}$ \\
\hline (1.0g ChNPs $/ \mathrm{kg}$ diet) B2 & 44.60 & $2563.5^{\mathrm{a}}$ & $2518.90^{\mathrm{a}}$ & $3940.4^{\mathrm{b}}$ & $1.57^{\mathrm{a}}$ \\
\hline SEM & 0.28 & 39.45 & 45.19 & 25.15 & 0.04 \\
\hline Sig. & NS & $* * *$ & $* * *$ & $* * *$ & $* * *$ \\
\hline \multicolumn{6}{|l|}{ Interaction $\mathrm{A} * \mathrm{~B}$} \\
\hline A1B1 & 44.10 & 2306.0 & 2261.9 & 4166.0 & 1.85 \\
\hline A1B2 & 45.40 & 2430.0 & 2384.6 & 3942.8 & 1.65 \\
\hline A2B1 & 44.20 & 2450.0 & 2405.8 & 4211.0 & 1.75 \\
\hline A2B2 & 43.80 & 2697.0 & 2653.2 & 3938.0 & 1.49 \\
\hline SEM & 0.24 & 47.18 & 40.25 & 36.45 & 0.03 \\
\hline Sig & NS & NS & NS & NS & NS \\
\hline
\end{tabular}

There was no adverse effect of RSM on feed intake of broiler chicks and Japanese quail, as shown by Osman et al. (2004) and El-Shafei et al. (2007). Shakmak (2008) indicated that growth of chicks was significantly affected by dietary inclusion of $25 \%$ rocket meal of soybean meal.

El-Shafei et al. (2007) indicated that RSM could be used up to $15 \%$ in the diet for growing Japanese quail without any adverse effect on growth performance. While Fagbenro (2004) reviewed that RSM at $20 \%$ of total dietary protein did not affect growth of African catfish.

During the period from 0 to $42 \mathrm{~d}$. of age, there were significant differences ( $\mathrm{P} \leq 0.01)$ in FBW, BWG, FI and FCR of chicks in response to dietary nano-chitosan supplementation, regardless of dietary protein source compared to the control group (Table 3).

The reason why the present growth performance (FBW, BWG and FCR) was improved is thought to be related to increased nutrient absorption which might enhanced by dietary nano-chitosan. Nanochitosan including diet had positive effects and can be used as a useful alternative to chitosan in broiler chickens' diets. Because chitosan had slow motility in the gastrointestinal lumen. It seems to stimulate the satiety center of the brain. Actually, in broiler chicks the capacity of the gastrointestinal tract is the limiting factor for feed intake (Leenstra, 1986 and McCarthy and Siegel, 1983). This suggests a possibility that the growth performance might be enhanced by feeding nano-chitosan-included diets but not the chitosan-supplemented diets.

Sayed et al. (2015) reported that Cobb 500 broiler chicks fed 10\% buckwheat supplemented with 250 and $500 \mathrm{mg}$ chitosan/kg displayed no significant differences in growth and feed intake. Because hazardous antibiotics are banned in poultry feed, including buckwheat with trace amounts of chitosan in broiler diets might be a useful alternative to antibiotics in the poultry industry.

A lot of animal studies have indicated that inclusion of chitosan at up to $50 \mathrm{~g} / \mathrm{kg}$ in feed had no adverse effects on the growth and feed intake of the treated animals (Kobayashi et al., 2006; Han et al., 2007; Khambualai et al., 2009; Yan \& Kim, 2011).

During the period from 0 to 6 weeks of age, there were no significant interaction between dietary protein source and feed additives on chicks' performance. 


\section{Blood parameters:}

Data in Tables (4 and 5) revealed a significant $(\mathrm{P}<0.01)$ effect dietary of protein source on serum total protein and globulin concentrations. Birds fed rocket seed meal-containing diets had higher levels of serum total protein and globulin compared with the control one. Feeding the RSM-diets significantly reduced serum levels of TG, LDL, and total lipids, and activity of AST and ALT compared with the control group. The differences between the control group and the RSM-fed group were not significant in terms of serum concentrations of albumin, total Chol. and HDL.

Table (4): Biochemical constituents of blood serum of 42-d. old broiler chicks fed diets containing two protein sources without or with nano-chitosan addition.

\begin{tabular}{|c|c|c|c|c|c|c|c|c|c|c|}
\hline Treatment & $\begin{array}{c}\text { TP } \\
\text { g/dl }\end{array}$ & $\begin{array}{l}\text { Alb } \\
\text { g/dl }\end{array}$ & $\begin{array}{l}\text { Glob. } \\
\text { g/dl }\end{array}$ & $\begin{array}{l}\text { Chol } \\
\text { mg/dl }\end{array}$ & $\begin{array}{c}\text { Tg } \\
\mathrm{mg} / \mathrm{dl}\end{array}$ & $\begin{array}{l}\text { HDL } \\
\mathrm{mg} / \mathrm{dl}\end{array}$ & $\begin{array}{c}\text { LDL } \\
\mathrm{mg} / \mathrm{dl}\end{array}$ & $\begin{array}{c}\text { T. lipids } \\
\text { mg/dl }\end{array}$ & $\begin{array}{l}\text { AST } \\
\text { U/dl }\end{array}$ & $\begin{array}{l}\text { ALT } \\
\text { U/dl }\end{array}$ \\
\hline \multicolumn{11}{|c|}{ Protein source $(\mathrm{A})$} \\
\hline Soybean meal (A1) & $4.13^{\mathrm{b}}$ & 2.26 & $1.88^{\mathrm{b}}$ & 174.30 & $147.48^{\mathrm{a}}$ & 50.61 & $94.19^{\mathrm{a}}$ & $617.37^{\mathrm{a}}$ & $74.97^{\mathrm{a}}$ & $25.90^{\mathrm{a}}$ \\
\hline Rocket seed meal (A2) & $4.80^{\mathrm{a}}$ & 2.46 & $2.34^{\mathrm{a}}$ & 163.23 & $131.42^{\mathrm{b}}$ & 59.53 & $77.42^{\mathrm{b}}$ & $530.77^{\mathrm{b}}$ & $61.57^{\mathrm{b}}$ & $20.48^{b}$ \\
\hline SEM & 0.14 & 0.09 & 0.08 & 4.10 & 4.23 & 4.22 & 4.77 & 18.22 & 2.79 & 1.74 \\
\hline Sig. & $* *$ & NS & $* *$ & NS & $*$ & $*$ & $*$ & $* * *$ & $* *$ & $*$ \\
\hline \multicolumn{11}{|c|}{ Nano-Chitosan level (B) } \\
\hline (0.0 g ChNPs $/ \mathrm{kg}$ diet) B 1 & 4.27 & 2.25 & 2.01 & 171.35 & 136.83 & 50.62 & $93.36^{\mathrm{a}}$ & $605.43^{a}$ & $73.14^{\mathrm{a}}$ & 25.24 \\
\hline (1.0 g ChNPs /kg diet) B2 & 4.66 & 2.46 & 2.20 & 166.18 & 142.07 & 59.52 & $78.25^{\mathrm{b}}$ & $542.70^{\mathrm{b}}$ & $63.40^{\mathrm{b}}$ & 21.14 \\
\hline SEM & 0.19 & 0.09 & 0.12 & 4.65 & 5.43 & 4.22 & 5.04 & 22.59 & 3.46 & 1.91 \\
\hline Sig. & NS & NS & NS & NS & NS & $*$ & * & $* *$ & $* *$ & NS \\
\hline \multicolumn{11}{|l|}{ Interaction $\mathbf{A} * \mathbf{B}$} \\
\hline A1B 1 & 3.95 & 2.17 & 1.78 & 177.73 & 146.10 & 49.08 & 99.43 & 662.30 & 79.92 & 28.00 \\
\hline A1B2 & 4.31 & 2.34 & 1.97 & 170.87 & 148.87 & 52.14 & 88.95 & 572.43 & 70.02 & 23.80 \\
\hline A2B 1 & 4.58 & 2.34 & 2.25 & 164.97 & 127.57 & 52.16 & 87.29 & 548.57 & 66.36 & 22.49 \\
\hline A2B2 & 5.01 & 2.57 & 2.43 & 161.50 & 135.27 & 66.89 & 67.55 & 512.97 & 56.78 & 18.47 \\
\hline SEM & 0.18 & 0.11 & 0.10 & 6.19 & 6.37 & 5.51 & 5.06 & 15.68 & 2.74 & 2.32 \\
\hline Sig. & NS & NS & NS & NS & NS & NS & NS & NS & NS & NS \\
\hline
\end{tabular}

${ }^{a \text { and } b}$ : Means in the same row having different superscripts differ significantly at $P \leq 0.05$. SEM: Standard error of the means. NS: Not significant; *, ** and ***: Significant at $P \leq 0.05,0.01$ and 0.001 , respectively.

Results of our study also revealed that chicks fed RSM-diet exhibited significant reduction in serum levels of total Chol., TG \& LDL while the level of HDL increased significantly. Reduced serum cholesterol level may be due to decreased absorption of dietary cholesterol from the intestinal lumen by plant sterols (Gupta et al., 1980). Blaževic and Mastelic (2008) found that Eugenol component in RSM inhibits peroxidation of lipids and causes hypocholestrolemia due to significant antioxidant action.

It was also reported that nutritional antioxidants increase HDL by activating sulfhydryl (SH) group of lecithin cholesterol acyl transferase (LCAT) enzyme (Wang and Ballatori, 1998). This enzyme incorporates free cholesterol from LDL into HDL and esterifies it (Eisenberg, 1984). The physiological action of T3 hormone is not only to stimulate the synthesis of cholesterol but also, its action in oxidation and biliary secretion. Hepatic uptake of cholesterol is increased by increasing expression of LDL receptors in liver. Therefore, the net effect is a significant decrease in plasma cholesterol and total lipids (Eisenberg, 1984 and Hubner et al., 1976).

The rats fed RSM-containing diet had reduced serum cholesterol levels (Al-Qudah and Amin 2017). Alam et al. (2006) reviewed that rats fed RSM-extract had potential renal protective activity, while Anac and Martin-Prevel (1999) and Bajilan and Al-naqeeb (2011) found that mice fed RSM-feeding extractsupplemented diet led to a weight loss in mice and may help in regulating cholesterol levels. 
Results showed also that both AST and ALT activity levels, as indicators of liver function, were significantly reduced in chicks fed Eruca sativa containing diet as compared to those of control group. It is well known activity of that ALT is more specific indicator of liver function tests as compared to that of AST. Since, ALT enzyme was only produced in the liver, while the AST enzyme is also produced in the kidneys, muscles, skeleton, brain and heart in addition to the liver (Yuliani et al., 2017). Eruca sativa was reported to have an antioxidant effect due to its free radicals scavenging activity in vivo (VillatoroPulido et al., 2012) and in vitro (Abbasi et al., 2013). Moreover, it has been reported to protect the hepatic injury through its potent antioxidant activity in vivo (Alqasoum et al., 2010).

On the other hand, insignificant differences were observed in most serum parameters among treatments, except levels of serum LDL and total lipids, and activity of AST which were significantly lower $(\mathrm{P}<0.01)$ in broilers that were fed on the diets fortified with nano-chitosan. Although serum TP, albumin, globulin, total Chol, TG, HDL and ALT concentration were not statistically different from those of the control group, the dietary supplementation of nano-chitosan caused a reduction of LDL level and liver enzymes activity. Similar findings were reported by Razdan and Pettersson (1994), who found that broilers fed chitosan-enriched diet displayed a reduction in plasma triglyceride concentrations on $11 \mathrm{~d}$. of age and plasma cholesterol concentrations on 11 and $19 \mathrm{~d}$. of age and the addition of chitosan at a low level was not able to reduce the concentrations of serum cholesterol and triglyceride in broilers.

Also, chitosan statistically reduced levels of total cholesterol, low-density lipoprotein cholesterol in plasma and total triglyceride in rat liver (Xu et al., 2007). Our results showed that the nano-chitosanadded diets had no effect on serum cholesterol and triglyceride of broilers compared with the control group. The results obtained agree with those reported by Nuengjamnong and Angkanaporn (2017), who found that feeding the broiler chicks on chitosan-supplemented diet had no effect on serum cholesterol and triglyceride.

Furthermore, the interaction between plant source of protein and feed additives had insignificant effect on all serum parameters presented in Tables (4 and 5).

Table (5): Biochemical constituents of blood serum of broiler chicks fed diets containing two protein sources with/ without nano-chitosan addition.

\begin{tabular}{|c|c|c|c|c|c|c|c|c|c|c|c|}
\hline Treatment & $\begin{array}{l}\text { ALP } \\
\text { U/dl }\end{array}$ & $\begin{array}{l}\text { IgG } \\
\mathrm{mg} / \mathrm{dl}\end{array}$ & $\begin{array}{l}\text { IgM } \\
\mathrm{mg} / \mathrm{dl}\end{array}$ & $\begin{array}{l}\operatorname{IgA} \\
\mathrm{mg} / \mathrm{dl}\end{array}$ & $\begin{array}{l}\text { CAT } \\
\text { U/ml/h }\end{array}$ & $\begin{array}{l}\text { TAC } \\
\mathrm{nmol} / \mathrm{ml}\end{array}$ & $\begin{array}{l}\text { MDA } \\
\mathrm{nmol} / \mathrm{ml}\end{array}$ & $\begin{array}{l}\text { SOD } \\
\text { U/ml/h }\end{array}$ & $\begin{array}{l}\text { T4 } \\
\mathrm{ng} / \mathrm{ml}\end{array}$ & $\begin{array}{l}\text { T3 } \\
\text { ng/ml }\end{array}$ & $\begin{array}{l}\text { FSH } \\
\text { ng/ml }\end{array}$ \\
\hline \multicolumn{12}{|c|}{ Protein source $(\mathbf{A})$} \\
\hline Soybean meal (A1) & $63.68^{\mathrm{a}}$ & $433.90^{\mathrm{b}}$ & $178.47^{\mathrm{b}}$ & $121.72^{b}$ & $53.87^{\mathrm{b}}$ & $1.65^{\mathrm{b}}$ & $28.90^{\mathrm{a}}$ & $64.00^{\mathrm{b}}$ & $20.12^{\mathrm{b}}$ & $3.62^{\mathrm{b}}$ & $1.99^{\mathrm{b}}$ \\
\hline Rocket seed meal (A2) & $47.45^{\mathrm{b}}$ & $513.78^{\mathrm{a}}$ & $221.85^{\mathrm{a}}$ & $142.33^{\mathrm{a}}$ & $71.32^{\mathrm{a}}$ & $1.88^{\mathrm{a}}$ & $19.06^{\mathrm{b}}$ & $85.40^{\mathrm{a}}$ & $23.22^{\mathrm{a}}$ & $4.81^{\mathrm{a}}$ & $4.61^{\mathrm{a}}$ \\
\hline SEM & 2.18 & 11.80 & 8.73 & 5.59 & 2.41 & 0.05 & 1.17 & 2.57 & 0.99 & 0.18 & 0.25 \\
\hline Sig & $* * *$ & $* *$ & $* *$ & $*$ & $* * *$ & $* *$ & $* * *$ & $* * *$ & $*$ & $* * *$ & $* * *$ \\
\hline \multicolumn{12}{|c|}{ Nano-Chitosan level (B) } \\
\hline (0.0 g ChNPs $/ \mathrm{kg}$ diet) B1 & 58.42 & 463.00 & 191.83 & 129.32 & $58.30^{\mathrm{b}}$ & 1.73 & 24.99 & 71.93 & 21.30 & $3.97^{\mathrm{b}}$ & $3.02^{\mathrm{b}}$ \\
\hline (1.0 $\mathrm{g} \mathrm{ChNPs} / \mathrm{kg}$ diet) B2 & 52.71 & 484.68 & 208.48 & 134.73 & $66.88^{\mathrm{a}}$ & 1.80 & 22.97 & 77.47 & 22.04 & $4.46^{\mathrm{a}}$ & $3.58^{\mathrm{a}}$ \\
\hline SEM & 4.04 & 20.85 & 12.51 & 7.15 & 4.17 & 0.07 & 2.45 & 5.29 & 1.19 & 0.30 & 0.63 \\
\hline Sig. & NS & NS & NS & NS & $* *$ & NS & NS & NS & NS & $*$ & $*$ \\
\hline \multicolumn{12}{|c|}{ Interaction $\mathbf{A} * \mathbf{B}$} \\
\hline A1 B1 & 65.73 & 431.20 & 178.43 & 116.20 & 48.77 & 1.65 & 29.22 & 62.00 & 18.58 & 3.24 & 2.13 \\
\hline A1B2 & 61.63 & 436.60 & 178.50 & 127.23 & 58.97 & 1.65 & 28.58 & 66.00 & 21.67 & 4.00 & 1.85 \\
\hline $\mathrm{A} 2 \mathrm{~B} 1$ & 51.11 & 494.80 & 205.23 & 142.43 & 67.83 & 1.81 & 20.77 & 81.87 & 24.02 & 4.69 & 3.91 \\
\hline $\mathrm{A} 2 \mathrm{~B} 2$ & 43.79 & 532.77 & 238.47 & 142.23 & 74.80 & 1.95 & 17.34 & 88.93 & 22.41 & 4.92 & 5.31 \\
\hline SEM & 2.74 & 16.00 & 11.02 & 8.40 & 2.24 & 0.06 & 1.64 & 3.52 & 1.29 & 0.21 & 0.19 \\
\hline Sig. & NS & NS & NS & NS & NS & NS & NS & NS & NS & NS & $* *$ \\
\hline
\end{tabular}

Table (5) showed significant increases in serum concentrations of IgG, IgM, IgA, CAT, TAC, SOD, T3, T4 and FSH in the treatment groups fed the RSM-supplemented diets compared to the control group 
$(\mathrm{P}<0.01)$. However, results showed significant reduction in the serum levels of ALP and MDA concentration in the supplemented groups as compared to control diet.

This effect may be due, in part to that RSM had an antioxidant activity as evidenced by decreasing serum level of the lipid peroxidation by-product (MDA), increasing content of reduced glutathione and restoring activities of antioxidant (SOD and CAT) enzymes.

In agreement with the present finding, Shalaby and Hammouda (2014) reported that feeding RSM-diet significantly increased the activity of SOD and CAT enzymes in when compared with control group.

Thyroid hormones are important for the growth and development of the body and regulation of metabolism (Huang et al., 2008). An increase in the production of thyroid hormones reflects an elevated activity of thyroid gland. Various pathological and physiological factors have been known to affect the concentration of these hormones and their metabolic activities. Serum levels of T4 and T3 of chicks fed RSM-containing diets were significantly $(\mathrm{P}<0.05)$ lower than those of the control group (Al-Mayali and Hasan, 2016). The reduction in of T4 could be due to the inhibition of 5-deiodinase (type 1) activity, which is responsible for the conversion of T3 to T4 (Maiti and Kar, 1997). Kale et al. (2007) mentioned that T3 and T4 secretion is in a negative correlation with the level of oxidative stress. On the other side, the antioxidant activity of Eruca sativa extract due to its constituents of flavonoids, saponin and vitamin C (Gauthaman et al., 2003).

The observed increase in the levels of $\mathrm{T} 3$ and $\mathrm{T} 4$ in our study may be due to an increase in the activity of thyroid gland by some compounds present in RSM. This explanation agrees with that reported by Al-Shaikh et al. (2014) who found that feeding albino-mice on RSM-containing diets had significant effects on physiology and function of follicular cells of the thyroid gland. RSM may also cause enhancement of the transport of sodium-iodide and increased absorption of iodide resulting in increased production of T3 and T4 and may influenced iodo-tyrosine deiodinase in rabbits fed RSM-containing diets (Yadav et al., 2016). In the fact, glucosinolates which are present in RSM have several biological activities including anti-carcinogenic, anti-fungal and anti-bacterial as well as their antioxidant properties (Kim et al., 2004).

Khoobchandani et al. (2012) reported that parsley and Eruca sativa oil given orally has been reported to significantly increase the concentration of $\mathrm{T} 4$ and $\mathrm{T} 3$ in hypothyroidism in rats as compared to untreated rats. It is apparent that recovery of thyroid parenchyma is related to protection offered by Eruca sativa (Khoobchandani et al., 2012) against hyperplastic changes that well known to be associated with hypothyroid status.

These results are in agreement with other researches using different medicinal plants like rocket which might reflect their antioxidant effects (El-Missry and El- Gindy, 2000), or due to the presence of phenolic compounds which exerted their modulator actions (Saleh et al., 1995) and improvement of the status of antioxidant enzymes (Martinez-Sanchez et al., 2007 and Ettebong and Nwafor, 2009).

Few observations reported that the presence of sterols, flavonoids, quercetin and saponins in Eruca sativa which can scavenge or remove free radicals which may cause an improvement the fertility and testicular functions (Agarwal and Allamaneni, 2011 and Ansari et al., 2014). Eruca sativa increased levels of serum FSH concentration (Nowfel and Al-Okaily, 2017).

Recently, Al-Tohamy et al. (2010) showed that the presence of glucosinolates (the major glucosinolate is Erucin) and other stimulant materials in Eruca sativa seeds have several biological activities and potentially capable for protecting the cells against oxidative stress resulting in an amelioration in semen characters and fertility in male rabbits (Talalay and Fahey, 2001).

Accordingly, the positive actions of Eruca sativa on the hormonal profile support the folkloric beneficial effect of the plant in the management of reproductive dysfunction.

It is reported that rocket seed oil is widely used by males to improve their sexual performance; the valuable effects of the oil are usually related to its fatty acid contents (Salem and Moustafa, 2001).

Hussein (2013) and Salem and Moustafa (2001) demonstrated that Eruca sativa leaves (which contain steroids, alkaloids, flavonoids, terpenes, glycosides and saponins) and seed oil has beneficial effects on fertility and male reproductive system. Moreover, several studies have shown that the aqueous extract as well as ethanolic extract of Eruca sativa plant increase spermatogenesis (Hussein, 2013 and El-Gayar $e t$ al., 2016). Intake of Eruca sativa leaves as a salad may be helpful for diabetic patients to minimize the reproductive performance deterioration (Ansari et al., 2014). 
Inversely, results as shown in Table (5) revealed positive effects of enriching diets with nano-chitosan on the antioxidant defense system compared to control one. The present results showed a positive effect in serum $\operatorname{IgG}, \operatorname{IgM}, \operatorname{Ig} \mathrm{A}, \mathrm{TAC}, \mathrm{SOD}$ and $\mathrm{T} 4$.

Conversely, our results showed reduction in serum ALP and MDA. On the other hand, dietary inclusion of nano-chitosan led to a significant increase in serum levels of CAT, T3 and FSH as compared to the control group.

On the other side, the interactions between added dietary RSM and fortification with nano-chitosan in Table (5) revealed insignificant $(\mathrm{P}<0.01)$ effects on serum levels of antioxidant defense and immunity system parameters in all groups.

\section{Evaluation of gene expression activity:}

As confirmed by previous results, the expression levels for IGF-1, PPAR $\alpha$ and PPAR $\gamma$ genes in the liver tissue of different experimental groups were analyzed and normalized to the expression of $\beta$-act and GAPDH genes. The relationship between normalized data to $\beta$-act and GAPDH genes (Fig. 3) was linear with a highly significant positive correlation $(\mathrm{r}=0.999 * *)$, demonstrating high accuracy of the measurement and gives higher reliability to our results.

Relative expression patterns of $I G F-1, P P A R \alpha$ and $P P A R \gamma$ genes in liver tissue taken immediately after slaughter from broiler chickens fed on SBM and RSM without or with nano-chitosan were illustrated in (Fig. 4).

Insignificantly differences for gene expression levels of IGF-1 and PPAR $\alpha$ genes were recorded among all experimental birds. However, the chicks fed RSM diet displayed the best in terms of the transcription level for the IGF-1 gene. This refers that the activity of growth factor IGF-1 and fatty acid oxidation was not affected with feeding on the RSM-diets without or with nano-chitosan, though the activity of growth factor $I G F-1$ was enhanced by feeding on RSM-diet. While, the PPAR $\gamma$ gene showed a decreases in transcriptional activity in chickens fed on RSM without or with nano-chitosan. Such a decrease was greater and significant in chickens fed on RSM-diet with nano-chitosan (mean of FC was $0.145)$.

Correlation coefficients shown in Table 6 may dictate that there was no high correlation between $I G F-1$ activity and the performance traits of the experimental chicks, except in feed intake trait which its correlation was significantly positive. Insulin-like growth factor-1 is one of the principal binding proteins that have biological functions involved in growth, development, and differentiation. Rechler (1993) reported that the Insulin-like growth factors (IGF) are polypeptides that play an imperative role in cell growth and differentiation. Chesik et al. (2007) showed that IGF binding proteins extend the half-life of the IGFs and have shown to either inhibit or stimulate the growth promoting effects of the IGFs on cell culture. Beccavin et al. (2001) noticed that growth rates were associated with IGF-1 activity, supporting the hypothesis of a stimulatory role for both IGFs-1\&II during post-hatching growth of chickens. Guernec et al. (2004) demonstrated the IGF-1 was sensitive to nutrient supply in hatching chicks, and also that fasting reduced IGF-1 mRNA levels in muscles of older chickens. All of this information supports our results which have shown that growth rates were not affected by feeding the RSM-diets without or with nano-chitosan. The lack of a harmful effect on growth rate, reported here, would reflected on IGF-1 expression activity that was reported to be sensitive to the feeding system.

Table (6): Correlation coefficients between performance traits and means of relative expression for $I G F-1, P P A R \alpha$ and PPAR $\gamma$ genes recorded for all experimental groups of broilers.

\begin{tabular}{lccccccccccc}
\hline & FBW & BWG & FI & FCR & T3 & T4 & T. lipids & TG & Chol & LDL & HDL \\
\hline IGF-1 & -0.244 & -0.242 & $0.948^{*}$ & 0.528 & 0.135 & 0.291 & 0.083 & -0.738 & -0.088 & 0.242 & -0.299 \\
PPAR $\alpha$ & -0.135 & -0.131 & 0.810 & 0.397 & -0.218 & -0.398 & 0.400 & -0.286 & 0.200 & 0.147 & 0.004 \\
PPAR & $-0.936^{*}$ & $-0.935^{*}$ & 0.258 & 0.896 & $-0.962^{*}$ & -0.803 & $0.993^{* *}$ & 0.565 & $0.974^{*}$ & $0.942^{*}$ & -0.837 \\
\hline
\end{tabular}

$*$ and $* *$ significant values at 0.05 and 0.01 probability levels, respectively.

Also, from Figure 3 and Table 6 can notice that gene expression activity of PPAR $\alpha$ was not affected by feeding the RSM-diet without or with nano-chitosan and that the change in the expression activity of the gene was not correlated with any change in estimates of performance traits. These results may reflect the rate of fatty acid (FA) oxidation which increased by increasing gene expression of PPAR (Bell et al., 1998 and Pineda et al., 1999), since the latter was not affected by feeding on RSM-diet without or with nano-chitosan.

The significant positive correlation coefficients $(0.993 * *, 0.974 *$ and $0.942 *)$ between PPAR $\gamma$ relative gene expression in liver tissue and serum contents of total lipids, total cholesterol and low-density 
lipoprotein (Table 6), confirms the lipogenic effect of $P P A R \gamma$. By contrast, the relationship between $P P A R \gamma$ relative gene expression and final body weight, body weight gain and $\mathrm{T} 3$ hormone concentration were significantly negatively correlated $\left(-0.936^{*},-0.935^{*}\right.$ and $-0.962 *$, respectively).

The peruse of results (Table 6) and the results presented in Figure (4) for PPAR $\gamma$ relative gene expression under the influence of feeding the experimental diets, can help us to find a beneficial effect of added dietary RSM with nano-chitosan which regulated the metabolic processes of lipids in favor of broiler chicks. These results correspond to the findings of Abozid et al. (2014), who illustrated that rocket seed contained high amount of $\omega-3$ and $\omega-6$ fatty acids. These fatty acids have been reported to act as a hypolipidemic agent. Also, other previous reports have illustrated that dietary $\omega-3$ and $\omega-6$ fatty acids inhibit lipogenesis.

The most role of PPAR is initiating adipocyte differentiation and increasing fat deposits (Tontonoz et al., 1993 and Hua et al., 1995). Conclusively, feeding the RSM diets had a significant effect in reducing the lipogenesis in broiler chicks. This is extremely important for the health and nutritional value of their products.

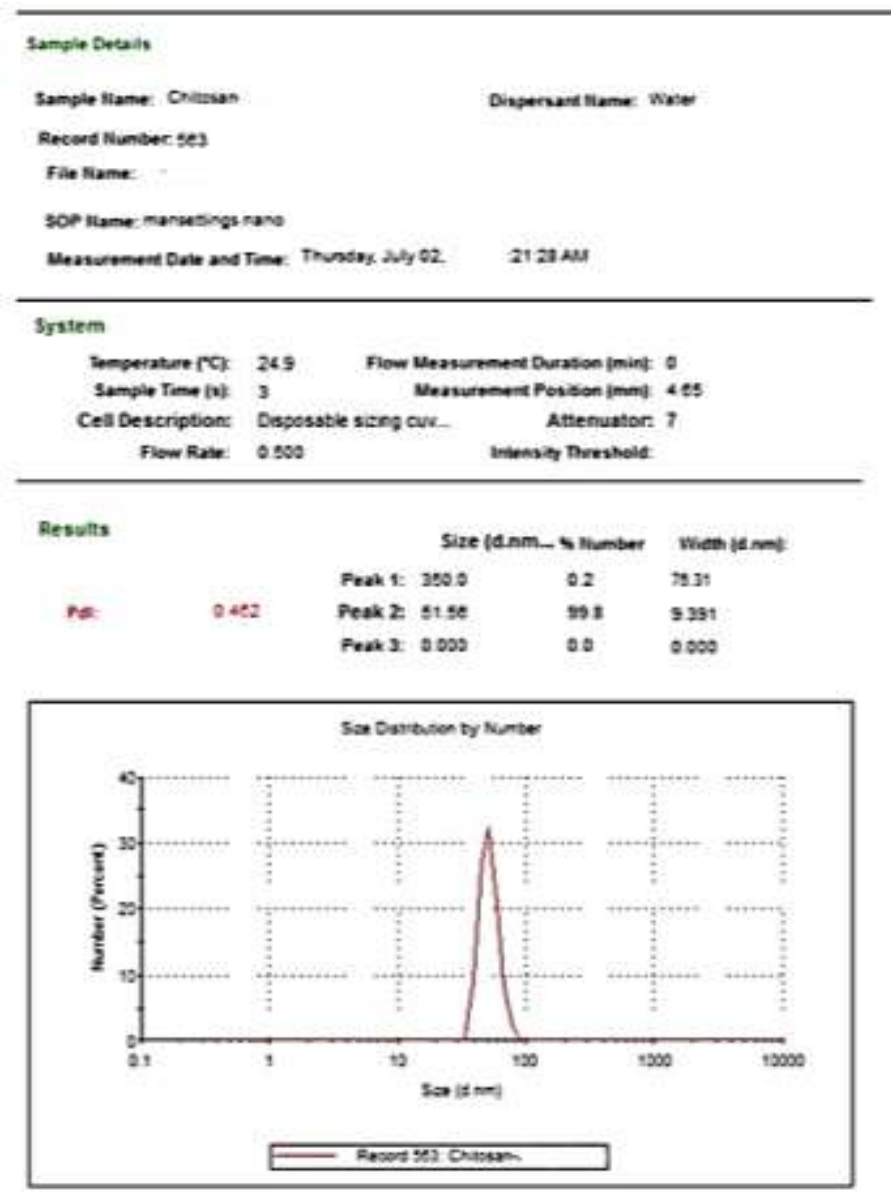

Fig. 1: Zeta sizer showed the size of nano-chitosan was between $30 \sim 40 \mathrm{~nm}$.

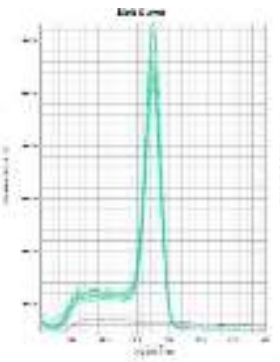

PPAR $\alpha$

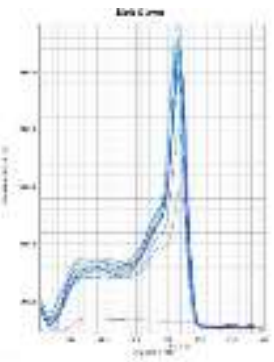

PPAR $\gamma$

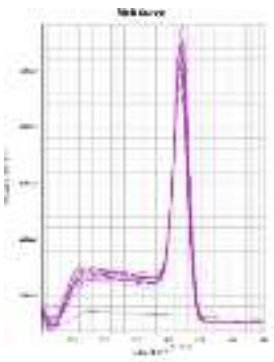

IGF-1

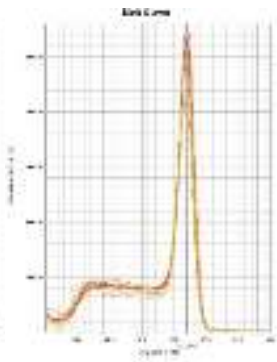

$\beta$-actin

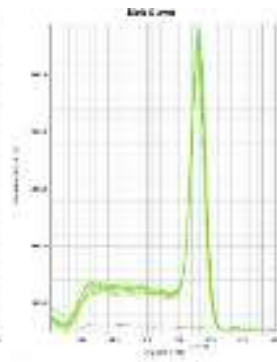

GAPDH

Fig. (2): Melting curves of single amplicon for target and reference genes of interest in this study. 


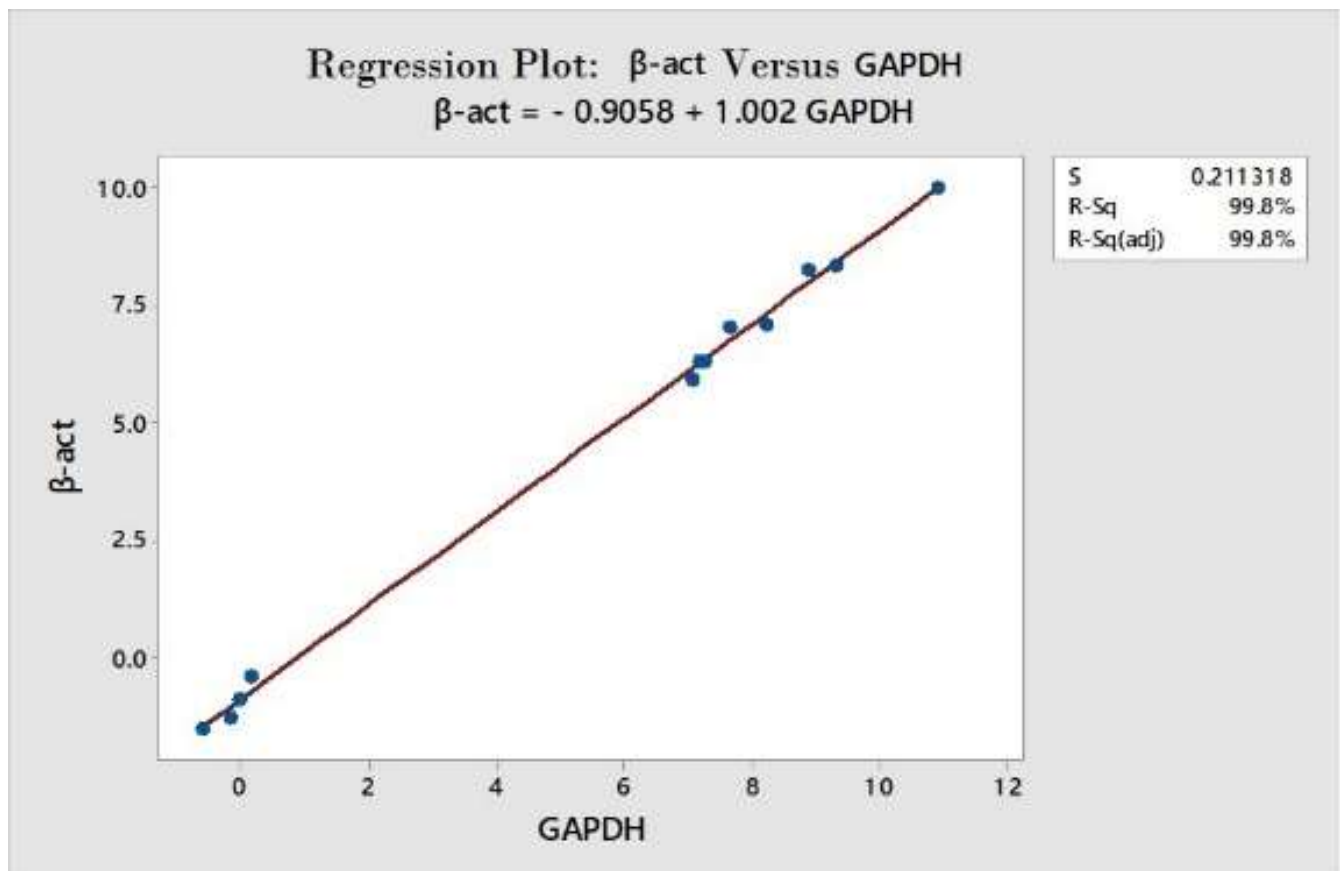

Fig. (3): Relationship between $\triangle C_{T}$ values for all interesting genes normalized to $\beta$-act and GAPDH gene expressions.

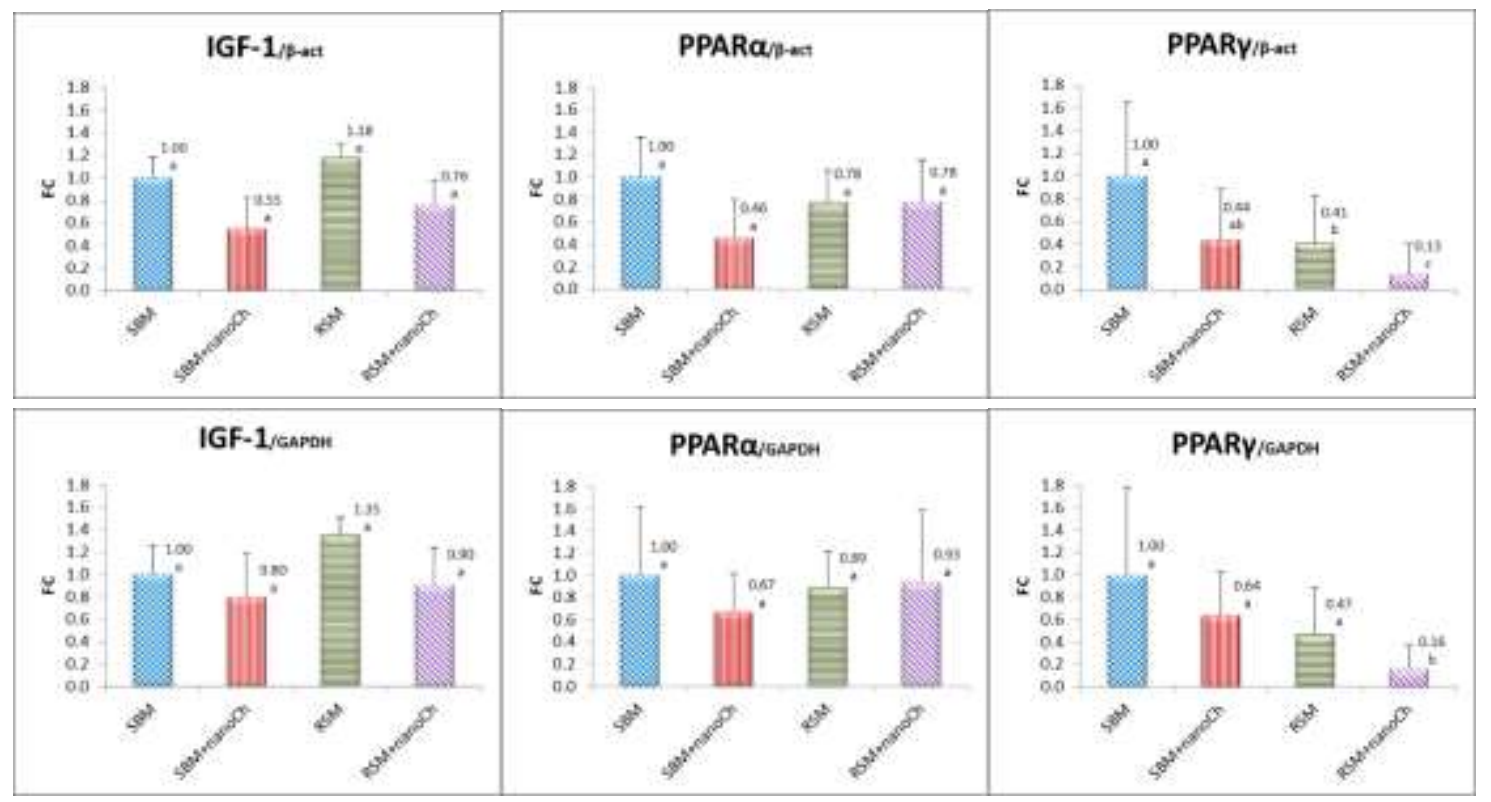

Fig. (4): Effect of different experimental diets on expression of IGF-1, PPAR $\alpha$ and PPAR $\gamma$ genes normalized to the expression of $\beta$-act and GAPDH reference genes in liver tissue.

\section{CONCLUSION}

It could be suggested using rocket seed meal (RSM) in broiler chicks diet up till $7.5 \%$ singly or in combination with nano-chitosan without any adverse effect on performance, blood biochemical and immunological responses and related gene expression criteria. Besides, a significant effect in reducing the lipogenesis in broiler chicks, this is extremely important for the health and nutritional value of their products. 


\section{REFERENCES}

Abbasi B. H.; Ali, J.; Ali, M.; Zia, M.; Bokhari, S.A. and Khan, M.A. (2013). Free radical scavenging activity in in vitro-derived tissues of Eruca sativa. ToxicolInd Health. [Epub ahead of print].

Abdo, Zeinab M.A. (2003). Using Egyptian Eruca sativa seed meal in broiler ration with or without microbial phytase. Egypt. J. Nutr.and Feeds. (6) Special Issue, 97-114.

Abo El-Maaty, Hayam M.A. (2009). Improving the utilization of plant protein sources by application. New Biotechnology in Poultry Diets. Ph.D. Thesis, Faculty of Agriculture, Mansoura University, Egypt.

Abozid, M.M.; Ashoush, Y.A.; Sakr, A.A.; Taha, K.M. and Ayimba, E. (2014). Evaluation of Egyptian Rocket seed oil as a source of essential fatty acids and its hypolipidemic effect in rats fed on high fat diet. International Journal of Advanced Research, 2(7): 434-441.

Agarwal, A.; Allamaneni, S.S. (2011). Free radicals and male reproduction. J. Indian Med. Assoc. 109: 184-187.

Alam, M.S.; Kaur, G.; Jabbar, Z.; Javed, K. and Athar, M. (2006). Eruca sativa seed possess antioxidant activity and exert a protective effect induced on mercuric chloride induced renal toxicity. Food and Chem Toxicol.,45:910-920.

Al-Mayali, H. K.A. and Hasan, Safa, M. K. (2016). Curative and protective roles of Eruca sativa M. leaves in ameliorating thyroid toxicity of malathion treated male rats. Online International Interdisciplinary Research Journal, \{Bi-Monthly\}, ISSN 2249-9598, Volume-VI, Issue-VI, Nov-Dec 2016 Issue.

Alqasoumi, S. (2010). Carbon tetrachloride-induced hepatotoxicity: Protective effect of Rocket (Eruca sativa $\mathrm{L}$ ) in rats. Am. J. Chin. Med.; 38 (1):75-88.

Al-Qudah, Maisa and Amin, M. (2017). Effects of Eruca sativa Leaves Extracts on Testes, Fertility Potential and Testosterone Concentration in Male Rats. Annual Research \& Review in Biology, 16 (6): 1-7.

Al-Shaikh, M. N.; AbdulWahab, T. Al. and Abdul-Kareem, Sahar, H. (2014). Hypothyroidism induced by carbimazole in diabetic mice and its Management Using Parsley and Eruca sativa oil. (IOSRJPBS. 9, 1: 24-27.

Al-Tohamy, M.M.; El-Nattat, W.S.I. and El-Kady, R.I. (2010). The beneficial of Nigella sativa, Raphannus sativus and Eruca sativa seed cakes to improve male rabbit fertility. Immunity and Production J. Am. Sci., 6: 1247-1255.

Anac, D. and Martin-Prevel, P. (1999). Improved crop quality by nutrients management. Kluwer Academic Publisher; pp:1-13.

Ansari, M.N.; Ganaie, M.A.; Khan, T.H. and Soliman, G.A.(2014). Protective effect of Eruca sativa against testicular damage in streptozotocin diabetic rats. Int. J. Biol. Pharm. Allied Sci. 3: 1067-1083.

A.O.A.C. (1990) Official Methods of Analysis. 15th Edition, Association of Official Analytical Chemist, Washington DC.

Attia, Y.A.; Aggoor, F.A.M.; Qota, Abo El-Maaty, Hayam M.A. (2003). Effect of dietary crude protein level, sources, and phytase addition on production performance, carcass characterisitics, meatqyality and plasma constituents of roasters. Egyption J. Nutrition and feed. 6 (special issue): 61-75.

Bajilan, S.I. and Al-naqeeb, A.A. (2011). Effect of the aqueous extract of rocket (Eruca sativa L.) leaves on the histological structure of some organs in male mice. Basic Science Journal, 70: 9.

Beccavin, C.; Chevalier B.; Cogburn1, L.A.; Simon, J. and Duclos, M.J. (2001). Insulin-like growth factors and body growth in chickens divergently selected for high or low growth rate. Journal of Endocrinology, 168: 297-306.

Bell, A.R.; Savory, R.; Horley, N.J.; Choudhury, A.I.; Dickins, T.J.; Gray, A.M., and Salter, D.R. (1998). Molecular basis of non-responsiveness to peroxisome proliferators: The guinea-pig PPAR alpha is functional and mediates peroxisome proliferator-induced hypolipidaemia. Biochem. J., 332, 689-693.

Beski, S. S.M.; Swick, R. A.; Iji, P. A. (2015). Specialized protein products in broiler chicken nutrition: A review. Animal Nutrition, 1(2): 47-53. https://doi.org/10.1016/j.aninu.2015.05.005

Blaževic, I. and Mastelic, J. (2008). Free and bound volatiles of rocket (Eruca sativa Mill.). Flavour Fragr. J., 23: 278-285. DOI: 10.1002/ffj.1883. 
Chesik, D.; De Keyser, J. and Wilczak, N. (2007). Insulin like growth factor binding protein-2 as a regulator of IGF actions in CNS: implications in multiple sclerosis. Cytokine Growth Factor Rev 18 (3-4): 267-278.

Duncan, D. B. (1955). Multiple range and multiple F tests. Biometrics, 11(1): 1-42.

Eisenberg S. (1984). High density lipoprotein metabolism. J Lipid Res.; 25: 107-58.

El-Gayar, H.A.; El-Habibi, E.M.; Edrees, G.M.; Salem, E.T. and Gouida, M.S. (2016). Role of alcoholic extracts of Eruca sativa or Petroselinumcrispum on dioxin-Induced testicular oxidative stress and apoptosis.Int J Sci Res., 5(1):1415-1421.

El-Missiry, M.A. and El-Gindy, A.M. (2000). Amelioration of alloxan induced diabetes mellitus and oxidative stress in rats by oil of Eruca sativa seeds. Ann. Nutr. Metab., 44: 97-100. https://doi.org/10.1159/000012829

El-Shafei, A. A.; Abdel-Rhman, Abeer S.; Amena, M.I.H. and E-Sisi, A. (2007). Effect of feeding variable rocket meal percentages on immune, biochemical and growth status of Japanese quail. Egypt. Poult. Sci., 27:663-688.

El-Tohamy, M. M. and El-Kady, R. I. (2007). Partial replacement of soybean meal with some medicinal plant seed meals and their effect on the performance of rabbits. International J. of Agric. and Biology., 9(2): 215-219.

Ettebong, E. and Nwafor, P., (2009). In vitro antimicrobial activities of extracts of Caepolobia lutea root. Pak. J. Pharma. Sci., 22: 335-338.

Fagbenro, O.A. (2004). Soybean meal replacement by roquette (Eruca sativa Miller) seed meal as protein feedstuff in diets for African catfish, Clarias gariepinus (Burchell 1822), fingerlings. Aquaculture research, 35: 917-923.

Friedewald, W.T.; Levy, R.I. and Fredrickson, D.S. (1972). Estimation of the concentration of low-density lipoprotein cholesterol in plasma, without use of the preparative ultracentrifuge. Clinical Chemistry, 18(6): 499-502.

Gauthaman, K.; Gansean, A. P. and Parasad, R. N. (2003). Sexual effects of puncture vine (Tribulus terrestris) extract protodioscin an evaluation using a rat model. J. Altern. Complement Med., 9(2): 257-65.

Guernec, A.; Chevalier, B. and Duclos, M.J. (2004). Nutrient supply enhances both IGF-I and MSTN mRNA levels in chicken skeletal muscle. Domastic Animal Endocrinology, (26): 143-154.

Gupta MB, Nath R, Srivastav N. (1980). Anti-inflammatory and antipyretic activities of betasitosterol. Planta Med., 39:157-63.

Han, K.N.; Kwon, I. K.; Lohakare, J. D.; Heo, S.andChae, B.J. (2007). Chitooligosaccharides as an alternative to antimicrobials in improving performance, digestibility and microbial ecology of the gut in weanling pigs. Asian Austral. J. Anim. Sci., 20, 556-562.

Heck, A.; Metayer, S.; Onagbesan, O.M. and Williams, J. (2003). mRNA expression of components of the IGF system an GH and insulin receptors in ovaries of broiler breeder hens fed ad libitum or restricted from 4 to 16 weeks of age. Domastic Animal Endocrinology, (25): 287-294.

Hua, X.; Wu, J.; Goldstein, J. L.; Brown, M.S.; Hobbs, H. H. (1995). Structure of the human gene encoding sterol regulatory element binding protein-1 (SREBF1) and localization of SREBF1 and SREBF2 to chromosomes 17p11.2 and 22q13. Genomics, 25, 667-673.

Huang, Y.H.; Tsai, M. M. and Lin, K.H. (2008) Thyroid hormone dependent regulation of target genes and their physiological significance. Chang Gung Med., J.; 31: 325-34.

Hubner, G.; Renner, K. and Rauer, G. (1976). The behavior of lipoproteins, cholesterol, triglycrides, fre fatty acids, and fre glycerol in serum of rats with experimental hyper thyroxemia and hypothyreosis. Endokrinologie, 67(1):60-66.

Hussein, Z.F. (2013). Study the effect of Eruca sativa leaves extract on male fertility in albino mice. J AlNahrain University, 16 (1):143-146.

Iqbal, M.; Lin, W.; Jabbal-Gill, I.; Davis, S.S. and Steward, M.W. (2003). Nasal delivery of chitosanDNA plasmid expressing epitopes of respiratory syncytial virus (RSV) induces protective CTL responses in BALB/c mice. Vaccine, 21: 1478-1485. 
Irish, G.G. and Balnave, D. (1993). Non-starch polysaccharides and broiler performance on diets containing soybean meal as the sole protein concentrate. Australian J. of Agric. Res., 44: 1483-1499.

Kale, M. K.; Umathe, S. N. and bhusari, K.P. (2007). Oxidative stress and the Thyroid. Positive Health.

Khambualai, O.; Yamauchi, K.; Tangtaweewipat, S. and Cheva-Isarakul, B. (2009). Growth performance and intestinal histology in broiler chickens fed with dietary chitosan, Br. Poult. Sci., 50: 592-597.

Khoobchandani, M.; Bansal P.; Medhe S.; Ganesh N. and Srivastava M. (2012) Antioxidant and Antimutagenic Activities of Isothiocyanates Rich Seed Oil of Eruca sativa Plant. In: Khemani L., Srivastava M., Srivastava S. (eds) Chemistry of Phytopotentials: Health, Energy and Environmental Perspectives. Springer, Berlin, Heidelberg. https://doi.org/10.1007/978-3-642-23394-4_10

Kim, S. J.; Jin, S. and Ishii G. (2004). Isolation and structural elucidat ion of 4-(B-dLucopyranosyldisulfanyl) butyl glucosinolate from leaves of rocket salad (Eruca sativa $\mathrm{L}$ ) and it antioxidative activity. Biosci. Biotech. Biochem., 68(12): 2444-2450.

Kobayashi, S.; Terashima, Y. and Itoh, H. (2006). The effects of dietary chitosan on liver lipid concentration in broiler chickens treated with propylthiouracil. J. Poult. Sci., 43: 162-166.

Konig, B.; Kluge, K.; Haase, K.; Brandsh, C.; Stangle, G.I.; Eder, K. (2007). Effects of clofibratetreatment in Laing hens. Poult. Sci., 86, 1187-1195.

Leenstra, F.R. (1986). Effect of age, sex, genotype and environment on fat deposition in broiler chickens; a review. World's Poultry Science Journal, 41:12-25.

Livak, K.J. and Schmittgen, T.D. (2001). Analysis of Relative Gene Expression Data Using Real-Time

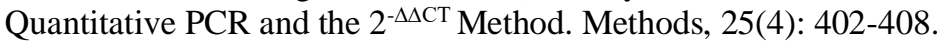

Maiti P.K.; Kar, A. (1997). Dimethoate inhibits extrathyroidal 5'-mono- deiodination of thyroxine to 3,3',5-triiodothyronine in mice: the possible involvement of the lipid peroxidative process. Toxicol. Lett., 91: 1-6.

Martinez-Sanchez, A.; Liorach, R.; Gil, M.I. and Ferreres, F. (2007). Identification of new flavonoid glycosides and flavonoid profiles to characterize rocket leafy salads (Eruca vesicaria and Diplotaxis tenuifolia). J. Agric. Food Chem., 55(4):1356-63. https://pubs.acs.org/doi/10.1021/jf063474b

McCarthy, J.C. and Siegel, P.B. (1983). A review of genetical and physiological effects on selection in meat-type poultry. Animal Breeding Abstracts, 51:87-94.

Navidshad, B. and Royan, M. (2015). Ligands and Regulatory Modes of Peroxisome ProliferatorActivated Receptor Gamma (PPAR $\gamma$ ) in Avians. Crit Rev Eukaryot Gene Expr., 25(4):287-292.

Neimert-Andersson, T.; Hällgren, A.C.; Andersson, M.; Langebäck, J.; Zettergren, L.; Nilsen-Nygaard, J.; Draget, K. I.; van Hage, M.; Lindberg, A.; Gafvelin, G. and Grönlund, H. (2011). Improved immune responses in mice using the novel chitosan adjuvant Visco Gel, with a Haemophilus influenzae type b glycoconjugate vaccine. Vaccine, 29(48), 8965-8973. https://doi.org/10.1016/j.vaccine.2011.09.041

Nowfel, A. J. and Al-Okaily, B.N. (2017). Oxidative stress: Role of Eruca sativa extract on male reproduction in rats. Adv. Anim. Vet. Sci., 5(1):39-46. http://dx.doi.org/10.14737/journal.aavs/2017/5.1.39.46

NRC, (1994). National Research Council. Nutrient requirements of poultry.9th edition, National Academy Press, Washington, D.C.

Nuengjamnong, Ch. and Angkanaporn, K., (2017). Efficacy of dietary chitosan on growth performance, haematological parameters and gut function in broilers, Italian Journal of Animal Science, http://dx.doi.org/10.1080/1828051X.2017.1373609

Osman, M.; Amber, K.H. and Mahmoud, M. A. (2004). Response of broiler chicks performance to partial dietary inclusion of radish, Rocket and parsley cakes. Egypt. Poult. Sci., 24: 429-446.

Pineda Torra, I.; Gervois, P. and Staels, B. (1999). Peroxisome proliferator activated receptor alpha in metabolic disease, inflammation, atherosclerosis and aging. Curr. Opin. Lipidol., 10: 151-159.

Razdan, A. and Pettersson, D. (1994). Effect of chitin and chitosan on nutrient digestibility and plasma lipid concentrations in broiler chickens. Br. J. Nutr., 72: 277-288.

Rechler, M.M. (1993). Insulin-like growth factor binding proteins.Vitam. Horm., 47: 1-114. 
Saleh, N.; Miller, N.J.; Pagang G.; Tijburg, L. and Bolwell, G.P. (1995). Rice polyphenolic flavanols as scavengers of aqueous phase radicals breaking antioxidant. Arch. Biochem. Biophys., 322: 339-346. https://doi.org/10.1006/abbi.1995.147

Salem, M. A. and Moustafa, N.A. (2001). Histological and quantitative study of the effect of Eruca sativa Seed oil on the testis of albino rat. Egyptian J. Hosp. Med., 2:148 -162.

SAS Institute, (2004). SAS® User's Guide for personal computer. SAS Institute Inc., Cary, NC. USA.

Sayed, M. A.; Islam, M.T.; Haque, M.M.; Shah, M.J.H.; Ahmed, R.; Siddiqui, M.N. and Hossain, M.A. (2015). Dietary effects of chitosan and buckwheat (Fagopyrumsculentum) on the performance and serum lipid profile of broiler chicks. South African Journal of Animal Science 2015, 45 (No. 4): 429440. http://dx.doi.org/10.4314/sajas.v45i4.9

Shakmak, El-S. A. M. (2008). Improving the utilization of some feedstuff in poultry diets. Ph.D. Thesis, Poultry Production Department, Faculty of Agriculture, Mansoura University.

Shalaby, M. A. and Hammouda, A. A. (2014). Nephroprotective, diuretic and antioxidant effects of some medicinal herbs in gentamicin-nephrotoxic rats. J. Intercult Ethnopharmaco, 3(1):1-8. http://dx.doi.org/10.5455/jice.20131130022009

Talalay, P. and Fahey, J.W. (2001). Phytochemicals from cruciferous plant protect against cancer by modulating carcinogen metabolism. J. Nutr. 131: 3027S-3033S.

Tontonoz, P.; Kim, J.B.; Graves, R.A.; Spiegelman, B.M. ADD1 (1993). A novel helix-loop-helix transcription factor associated with adipocyte determination and differentiation. Mol. Cell. Biol., 13, 4753-4759.

Villatoro-Pulido, M.; Font, R.; Saha, S.; Obregón-Cano, S. and Anter, J. (2012). In vivo biological activity of rocket extracts (Erucavesicaria subsp. sativa (Miller) (Thell) and sulforaphane. Food Chem. Toxicol., 50(5):1384-92.

Wahle, K.W.; Braissant, O. and Desvergne, B. (1995). Peroxisome proliferator activated receptors: Transcriptional regulators of adipogenesis, lipid metabolism and more. Chem. Biol., 2, 261-266.

Wahle, K.W.; Rotondo, D. and Heys, S.D. (2003). Polyunsaturated fatty acids and gene expression in mammalian systems. Proc. Nutr. Soc., 62, 349-360.

Wang, W. and Ballatori, N. (1998). Endogenous glutathione conjugates: Occurance and biological functions. Pharmacol. Rev., 50:335-354.

Wen, Z. Sh. Un.; Xu, Y. L.; Zou, X. T. and Xu Z. R. (2011). Chitosan Nanoparticles Act as an Adjuvant to Promote both Th1 and Th2 Immune Responses Induced by Ovalbumin in Mice. Mar Drugs., 9(6): 1038-1055. http://dx.doi.org/10.3390/md9061038

Xu, G.; Huang, X.; Qiu, L.; Wu, J. and Hu, Y. (2007). Mechanism study of chitosan on lipid metabolism in hyperlipidemic rats. Asia Pac. J. Clin. Nutr., 16:313-317.

Yadav, M.; Sethi J. and Dahiya, K. (2016). Effect of ocimum sanctum on serum concentration of thyroid hormones and atherogenic profile in rabbits. Int J. Health Sci. Res., 6(12):97-101.

Yan, L. and Kim, H. I. (2011). Evaluation of dietary supplementation delta-aminolevulinic acid and chitooligosaccharide on growth performance, nutrient digestibility, blood characteristics and fecal microbial shedding in weaned pigs. Anim. Feed Sci. Technol. 169, 275-280.

Yasser, A.A.; El-Nomeary; El- Kady R.I. and El-Shahat A.A. (2015). Effect of Some Medicinal Plant Seed Meals Supplementation and their Effects on the Productive Performance of Male Rabbits. Int. J. Chem. Tech. Res., 8(6): 401-411.

Yuliani, Y.; Isnurhadi, I. and Jie, J. (2017). Risk perception and psychological behavior of investors in emerging market: Indonesian Stock Exchange. Investment Management and Financial Innovations, 14(2-2), 347-358. http://dx.doi.org/10.21511/imfi.14(2-2).2017.06

Zheng, Y.; Kovacs J.R.; Gawalt E.S.; Hongmei Shen and Meng W.S. (2006). Characterization of particles fabricated with poly (D, L-lactic-co-glycolic acid) and an ornithine-histidine peptide as carriers of oligodeoxynucleotide for delivery into primary dendritic cells. J. Biomater Sci. Polym. Ed., 17: 13891403. 
تأثير التغذية على العلائق المحتوية على كسب بذور الجرجير والمدعمة بالنانوشيتوزان على الأداء الإنتاجى

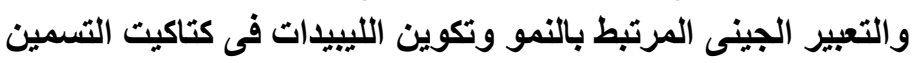

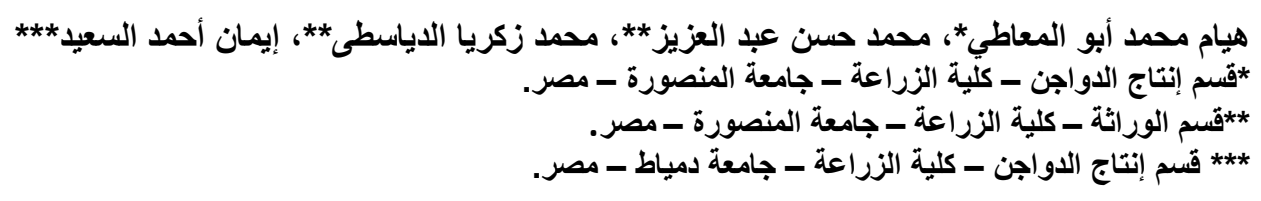

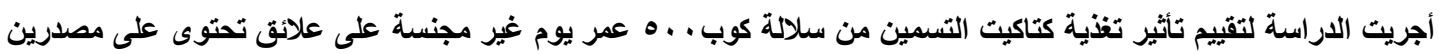

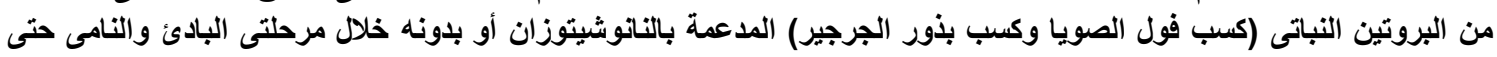

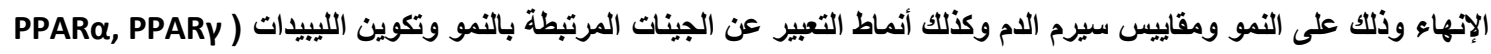
(IGF-1,

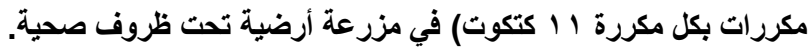

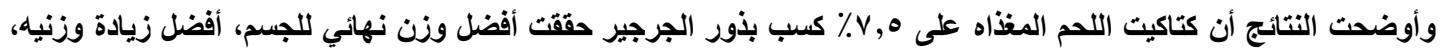

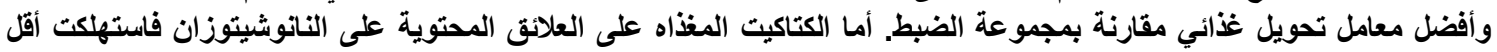

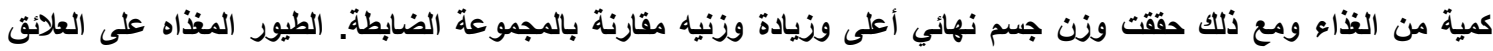

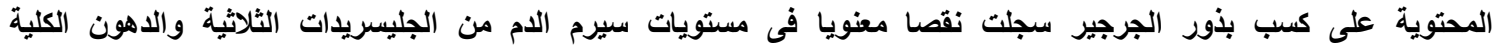

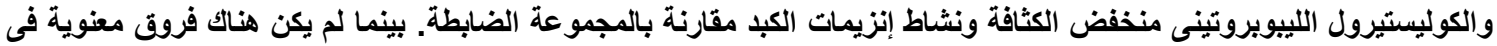
مستويات السيرم من الألبيومين، الكوليستيرول الكلى، والكوليستيرول الليبويروتيني مرتفع الكثافة.

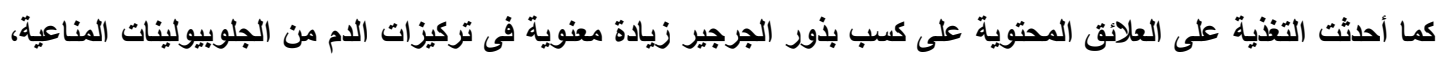

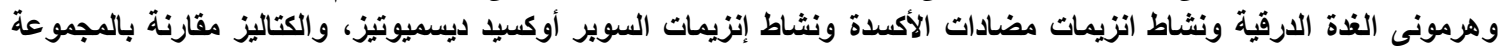

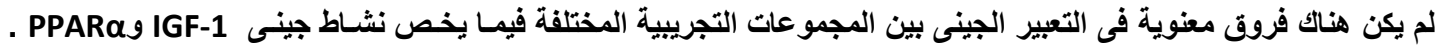

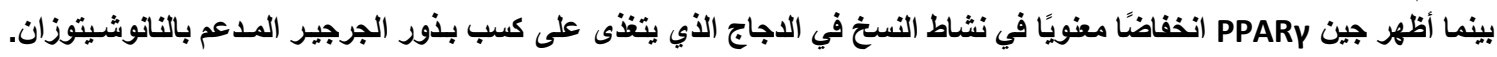

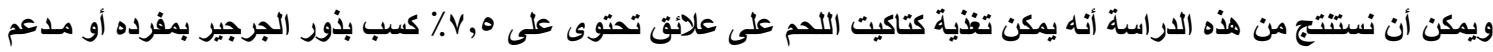

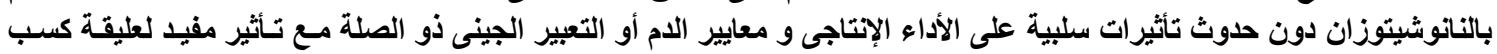

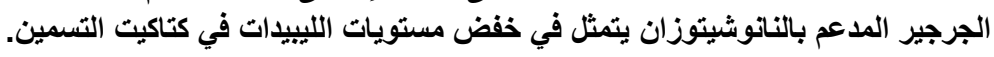

